\title{
Wetting and Interfacial Chemistry of Sn-Zn-Ga Alloys with Cu Substrate
}

\author{
Tomasz Gancarz and Przemyslaw Fima
}

(Submitted October 27, 2015; in revised form February 14, 2016; published online April 4, 2016)

\begin{abstract}
Wetting of $\mathrm{Cu}$ pads by $\mathrm{Sn}-\mathrm{Zn}$ eutectic-based alloys with $0.1,0.2,0.5$, and $1.0 \mathrm{wt.} \%$ of Ga was studied using the sessile drop method in the presence of $A \mathbf{L U 3 3}{ }^{\circledR}$ flux. Wetting tests were performed at $250{ }^{\circ} \mathrm{C}$ after 60 , $180,480,900,1800$, and 3600 s of contact, and at $230,280,320{ }^{\circ} \mathrm{C}$ for a contact time of $480 \mathrm{~s}$. After cleaning the flux residue from solidified samples, the spreadability of $\mathrm{Sn}-\mathrm{Zn}-\mathrm{Ga}$ on $\mathrm{Cu}$ was determined in accordance with ISO 9455-10:2013-03. Selected, solidified solder-pad couples were cross-sectioned and subjected to scanning electron microscopy with energy dispersive spectroscopy and $x$-ray diffraction study of the interfacial microstructure. Growth of the intermetallic $\mathrm{Cu}_{5} \mathrm{Zn}_{8}$ and $\mathrm{CuZn}$. phase layers was studied at the solder-pad interface. Samples after spreading test at $250^{\circ} \mathrm{C}$ for $60 \mathrm{~s}$ were subjected to aging for 1,10 , and 30 days at $170{ }^{\circ} \mathrm{C}$.
\end{abstract}

Keywords intermetallics, microstructure, Sn-Zn-Ga, wettability

\section{Introduction}

Sn-Zn-based alloys are a group of alloys of particular interest as $\mathrm{Pb}$-free solders in the electronics industry. It has been reported that alloying elements such as $\mathrm{Ag}, \mathrm{Al}, \mathrm{Bi}, \mathrm{Cu}$, etc. were added to $\mathrm{Sn}-\mathrm{Zn}$ eutectic $\left(\mathrm{Sn}-\mathrm{Zn}_{\text {eut }}\right)$ to improve its wetting, mechanical properties, and corrosion resistance (Ref 1, 2). The Ga element, unlike many others, does not form intermetallic compounds (IMCs) with $\mathrm{Sn}$ and $\mathrm{Zn}$, and exhibits a relatively broad range of solid solubility in both $\mathrm{Sn}$ and $\mathrm{Zn}$ (Ref 3, 4). Song et al. (Ref 5), Hung et al. (Ref 6), and recently Gancarz (Ref 7) studied the effect of Ga concentration (up to 1.8, 0.8, and $3.0 \mathrm{wt} . \%$, respectively) on the microstructure of cast alloys. They observed coarsening of $\mathrm{Zn}$-rich precipitates and increasing size of the Sn-phase, as Ga content increased. Due to its low melting temperature $\left(29.8^{\circ} \mathrm{C}\right)$, even small additions of $\mathrm{Ga}$ to $\mathrm{Sn}-\mathrm{Zn}$ eutectic decreases the melting temperature, yet, the solidus decreases faster than the liquidus, resulting in broadening of the pasty range (Ref 5,8 ). Although Zhang et al. (Ref 8) were the first to present a ternary Sn-Zn-Ga phase diagram obtained by piecing binary phase diagrams, Zivkovic et al. (Ref 9) used the Calphad approach and thermodynamic descriptions of binary systems only, for that purpose. They found the calculated pseudo-binary $\left(\mathrm{Sn}-\mathrm{Zn}_{\text {eut }}\right)-\mathrm{Ga}$ diagram to be in agreement with transition temperatures determined with differential thermal analysis (DTA). Their calculations indicate that

This article is an invited submission to JMEP selected from presentations at the Symposium "Wetting and High-Temperature Capillarity," belonging to the Topic "Joining and Interfaces" at the European Congress and Exhibition on Advanced Materials and Processes (EUROMAT 2015), held September 20-24, 2015, in Warsaw, Poland, and has been expanded from the original presentation.

Tomasz Gancarz and Przemyslaw Fima, Institute of Metallurgy and Materials Science, Polish Academy of Sciences, 30-059 Krakow, Poland. Contact e-mail: p.fima@imim.pl. the solubility limit of $\mathrm{Ga}$ in solid $\mathrm{Sn}-\mathrm{Zn}_{\text {eut }}$ is about 5 at.\%, and that the Ga-rich liquid phase exists at room temperature above this threshold (Ref 9).

The increase of tensile strength of Sn-Zn-xGa alloys with Ga content, accompanied by decrease of elongation as observed in Ref 5-7, is caused by the solid solubility of Ga in Sn and Zn. Hung et al. (Ref 6), with the use of secondary ion mass spectrometry (SIMS), compared the thickness of the oxide film on the surface of as-cast Sn-9Zn and Sn-9Zn-0.4Ga (wt.\%) and found it to be $50 \%$ thinner in the latter case. Based on this, and on the thermal behavior of oxide film on Sn-9Zn-0.4Ga (wt.\%), they assumed that $\mathrm{Ga}$ increases oxidation resistance. The effect of $\mathrm{Ga}$ content (up to $3 \mathrm{wt}$.\%) on wetting on the $\mathrm{Cu}$ substrate, for $30 \mathrm{~s}$, at $235^{\circ} \mathrm{C}$, and on the thickness of the IMC interlayer formed, was studied only by Chen et al. (Ref 10). More recently, Ye et al. (Ref 11) characterized the microstructure of the interface between the $\mathrm{Sn}-9 \mathrm{Zn}-0.5 \mathrm{Ga}$ alloy and the $\mathrm{Cu}$ substrate after a wetting balance test at $235^{\circ} \mathrm{C}$ and subsequent aging for $100 \mathrm{~h}$ at $100{ }^{\circ} \mathrm{C}$. In this study, we investigated the effect of temperature and extended time of contact on the spreading areas of Sn-8.9Zn- $x \mathrm{Ga}$ alloys $(x=0.1,0.2,0.5$, 1.0 wt. $\%)$ on the $\mathrm{Cu}$ substrate, and on the interfacial microstructure of $\mathrm{Sn}-8.9 \mathrm{Zn}-x \mathrm{Ga} / \mathrm{Cu}$ joints. Selected joints were subjected to isothermal aging at $170{ }^{\circ} \mathrm{C}$ and the evolution of the interface was studied.

\section{Experimental}

Sn-8.9Zn- $x \mathrm{Ga}$ solder alloys $(x=0.1,0.2,0.5,1.0$ wt.\%) were prepared by melting precise amounts of high purity components: Sn, Zn, Ga (99.999 wt.\%). To avoid oxidation, alloys were melted in graphite crucibles, in a resistance-heated furnace placed in a glovebox filled with high purity $\operatorname{Ar}(6 \mathrm{~N})$. For spreading tests, the as-cast solders were cut into pieces of $\sim 0.2 \mathrm{~g}$ each and degreased with acetone. Except for degreasing, there was no special treatment of the $\mathrm{Cu}$ (99.9 wt.\%) substrates $(25 \times 20 \times 0.2 \mathrm{~mm})$. The tests were carried out with the setup earlier used in studies of Sn-Zn-X alloys (Ref 12), which enables the quick transfer of the sample to the already 
heated furnace, and out of it after the designated time of the test, so both the heating rate and cooling rate are high. To study the effect of extended time of contact and temperature on the evolution of the solder-substrate interface, samples were held at $250{ }^{\circ} \mathrm{C}$ for $60,180,480,900,1800$, and $3600 \mathrm{~s}$, and for $480 \mathrm{~s}$ at 230,280 , and $320^{\circ} \mathrm{C}$.

Wetting tests were performed with ALU33 $^{\circledR}$ flux $\left(\sim 0.05 \mathrm{~cm}^{3}\right)$ applied to the solder sample and surrounding part of the substrate. According to ISO 9454-1, this is 2.1.2-type flux, organic, water-soluble, and activated with halides. Its components are aminoethylethanolamine $\left(\mathrm{C}_{4} \mathrm{H}_{12} \mathrm{~N}_{2} \mathrm{O}\right)$ and ammonium fluoroborate $\left(\mathrm{NH}_{4} \mathrm{BF}_{4}\right)$. The reported spreading areas are the average of three measurements on independent solidified samples after washing flux residue with tap water. After wetting tests, selected solidified solder/substrate couples were cut perpendicular to the plane of the interface, mounted in conductive resin and polished for microstructural characterization. Selected samples, after spreading test for $60 \mathrm{~s}$ at $250{ }^{\circ} \mathrm{C}$, were subjected to aging at $170{ }^{\circ} \mathrm{C}$ for 24,240 , and $720 \mathrm{~h}$. The microstructural and energy dispersive spectroscopy (EDS) analysis were performed using the Quanta 3D FEG system, at $20 \mathrm{kV}$, with the standardless Analysis EDAX System based on Genesis 4000 software.

\section{Results and Discussion}

\subsection{Solder-Substrate Interaction}

The spreading areas of $\mathrm{Sn}-8.9 \mathrm{Zn}-x \mathrm{Ga}$ alloys on $\mathrm{Cu}$ substrate after wetting at $250{ }^{\circ} \mathrm{C}$ for the designated time are presented in Fig. 1(a). With increasing time of contact, spreading areas of solders do not increase. On the contrary, the highest average value of the spreading area is observed after $60 \mathrm{~s}$. In particular, for alloys containing 0.1 and $0.2 \mathrm{wt} . \% \mathrm{Ga}$, the spreading area is about the same, whereas for alloys containing 0.5 and 1.0 $\mathrm{wt} . \% \mathrm{Ga}$, there is a tendency for the spreading area to decrease as time of contact increases. The spreading area of the Sn$8.9 \mathrm{Zn}-1.0 \mathrm{Ga}$ alloy after $1800 \mathrm{~s}$ is $30 \%$ lower than for the same alloy after $60 \mathrm{~s}$. Considering that the estimated error of the determined spreading area is up to $5 \%$, this is not a big difference. Figure 1(b) illustrates the spreading area determined after $480 \mathrm{~s}$ at the designated temperature. One can see that, at 250,280 , and $320{ }^{\circ} \mathrm{C}$, the spreading area is about $40 \mathrm{~mm}^{2}$, whereas at $230{ }^{\circ} \mathrm{C}$, the spreading area shows a decreasing tendency with increased Ga content, although the effect is not so clear considering the error bars. The average value of the spreading area is smaller than $\sim 50 \mathrm{~mm}^{2}$ reported for Sn-9Zn$x \mathrm{Ga}(x=0.1 \div 3$ wt.\%) alloys (Ref 10). Chen et al. (Ref 10) showed that the spreading area, determined at $235{ }^{\circ} \mathrm{C}$ for solder samples of $0.2 \mathrm{~g}$, increases with increasing $\mathrm{Ga}$ content, and above 0.5 wt. $\% \mathrm{Ga}$ stabilizes at a constant level. When comparing the results of spreading area, it is important to remember that the spreading areas reported in Ref 10 were determined after $30 \mathrm{~s}$, while the results presented in this paper (Fig. 1b) were determined after $480 \mathrm{~s}$. While the main reason for this discrepancy is likely to be different flux, the type of flux and its activity was not specified in Ref 10 .

The microstructures of $\mathrm{Sn}-\mathrm{Zn}_{\text {eut }}$ alloys with $0.5 \mathrm{wt} . \% \mathrm{Ga}$ on $\mathrm{Cu}$ substrates after spreading at $250{ }^{\circ} \mathrm{C}$ for a contact time of: (a) 60; (b) 180; (c) 480; (d) 900; (e) 1800; (f) $3600 \mathrm{~s}$, are presented in Fig. 2. For alloys containing 0.1, 0.2, and $1.0 \mathrm{wt} . \% \mathrm{Ga}$, the interfacial microstructure looks similar, with intermediate layers at the interface composed of IMCs from the $\mathrm{Cu}-\mathrm{Zn}$ system. The curves labeled SnL (red), CuK (green), ZnK (dark blue), GaK (light blue) represent EDS line scan results along the bright line perpendicular to the plane of interface. Starting from the $\mathrm{Cu}$ substrate, concentration of $\mathrm{Cu}$ decreases from 100 to $~ 35 \mathrm{wt} . \%$ in $\mathrm{Cu}_{5} \mathrm{Zn}_{8}, \sim 20$ wt.\% in $\mathrm{CuZn}_{4}$, and 0 in $\mathrm{Sn}-8.9 \mathrm{Zn}-\mathrm{xGa}$ alloy. One can see that concentrations of $\mathrm{Ga}$ and $\mathrm{Sn}$ in the intermediate layers are close to zero. After $60 \mathrm{~s}$ of contact time, an interlayer $(\sim 1 \mu \mathrm{m})$ is observed, which is composed of $\mathrm{Cu}_{5} \mathrm{Zn}_{8}$ and $\mathrm{CuZn}_{4}$. On the other hand, Chen et al. (Ref 10) reported that only a $\mathrm{Cu}_{5} \mathrm{Zn}_{8}$ IMC layer is formed at the interface, after $30 \mathrm{~s}$ at $235{ }^{\circ} \mathrm{C}$, followed by slow cooling in the furnace. Ye et al. (Ref 11) showed an optical micrograph of the


Fig. 1 Spreading area of Sn-8.9Zn- $x$ Ga alloys on $\mathrm{Cu}$ : (a) effect of time of contact, (b) effect of temperature 


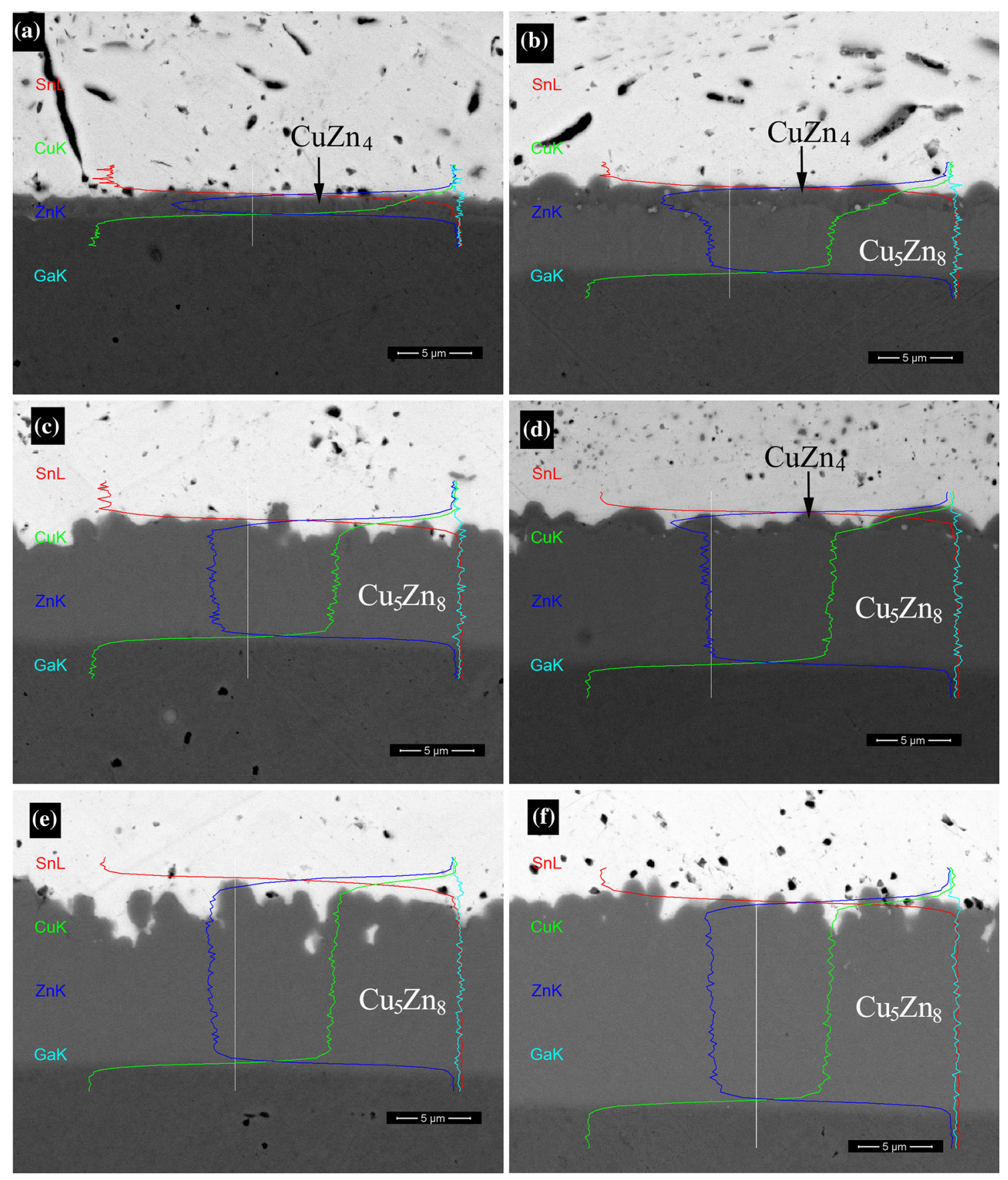

Fig. 2 Interfacial microstructure of $\mathrm{Sn}-8.9 \mathrm{Zn}-0.5 \mathrm{Ga} / \mathrm{Cu}$ couples at $250{ }^{\circ} \mathrm{C}$ after the designated time of contact: (a) $60 \mathrm{~s}$, (b) $180 \mathrm{~s}$, (c) $480 \mathrm{~s}$, (d) $900 \mathrm{~s}$, (e) $1800 \mathrm{~s}$, (f) $3600 \mathrm{~s}$

Sn-9Zn-0.5Ga/Cu interface after a wetting balance test (immersion time $10 \mathrm{~s}$ ), where, of the two interlayers, only the thicker one from the side of substrate was labeled as $\mathrm{Cu}_{5} \mathrm{Zn}_{8}$. After $180 \mathrm{~s}$ (Fig. 2c) both sub-layers can be easily distinguished. These are $\mathrm{Cu}_{5} \mathrm{Zn}_{8}$ from the side of the substrate, and a thinner $\mathrm{CuZn} \mathrm{n}_{4}$ sublayer from the side of the solder. After $480 \mathrm{~s}$ the $\mathrm{Cu}_{5} \mathrm{Zn}_{8}$ is thicker, but $\mathrm{CuZn}_{4}$ appears thinner, and spots of discontinuity can be observed. With increasing contact time the $\mathrm{Cu}_{5} \mathrm{Zn}_{8}$ continues to grow, but no $\mathrm{CuZn}_{4}$ remains. The obtained microstructure of Sn$8.9 \mathrm{Zn}-x \mathrm{Ga}$ on the $\mathrm{Cu}$ substrate is similar to the $\mathrm{Sn}-\mathrm{Zn}-\mathrm{In} / \mathrm{Cu}$ interface (Ref 13). However, the $\mathrm{CuZn}_{4}$ layer is still present at the $\mathrm{Sn}-\mathrm{Zn}-\mathrm{In} / \mathrm{Cu}$ interface after a long contact time (3600 s), as opposed to the $\mathrm{Sn}-8.9 \mathrm{Zn}-x \mathrm{Ga} / \mathrm{Cu}$ interface. The microstructures of the $\mathrm{Sn}-\mathrm{Zn}-x \mathrm{Cu} / \mathrm{Cu}(\mathrm{Ref} 12)$ (time of contact up to $180 \mathrm{~s}$ ) and $\mathrm{Cu} / \mathrm{Sn}-\mathrm{Zn}-\mathrm{Ag}-\mathrm{Cu} / \mathrm{Cu}$ (Ref 14) joints differ from those of Sn$8.9 \mathrm{Zn}-x \mathrm{Ga} / \mathrm{Cu}$, because the IMCs from $\mathrm{Cu}-\mathrm{Zn}$ to $\mathrm{Ag}-\mathrm{Zn}$ systems are present in the solder. However, the microstructure of the Sn$\mathrm{Zn}-\mathrm{Ag}-\mathrm{Cu} / \mathrm{Cu}$ interface for a long contact time (1800 and $3600 \mathrm{~s}$ ) is similar to that of $\mathrm{Sn}-8.9 \mathrm{Zn}-x \mathrm{Ga} / \mathrm{Cu}$, with only one $\mathrm{Cu}_{5} \mathrm{Zn}_{8}$ layer observed at the interface.

Considering solubility of $\mathrm{Ga}$ in $\mathrm{Sn}$ and $\mathrm{Zn}(\operatorname{Ref} 3,4)$ it can be assumed that interfacial microstructures of Sn-8.9Zn- $x \mathrm{Ga} / \mathrm{Cu}$ couples may be similar to $\mathrm{Sn}-9 \mathrm{Zn} / \mathrm{Cu}$ couples and may similarly evolve in time. Although literature agrees that 

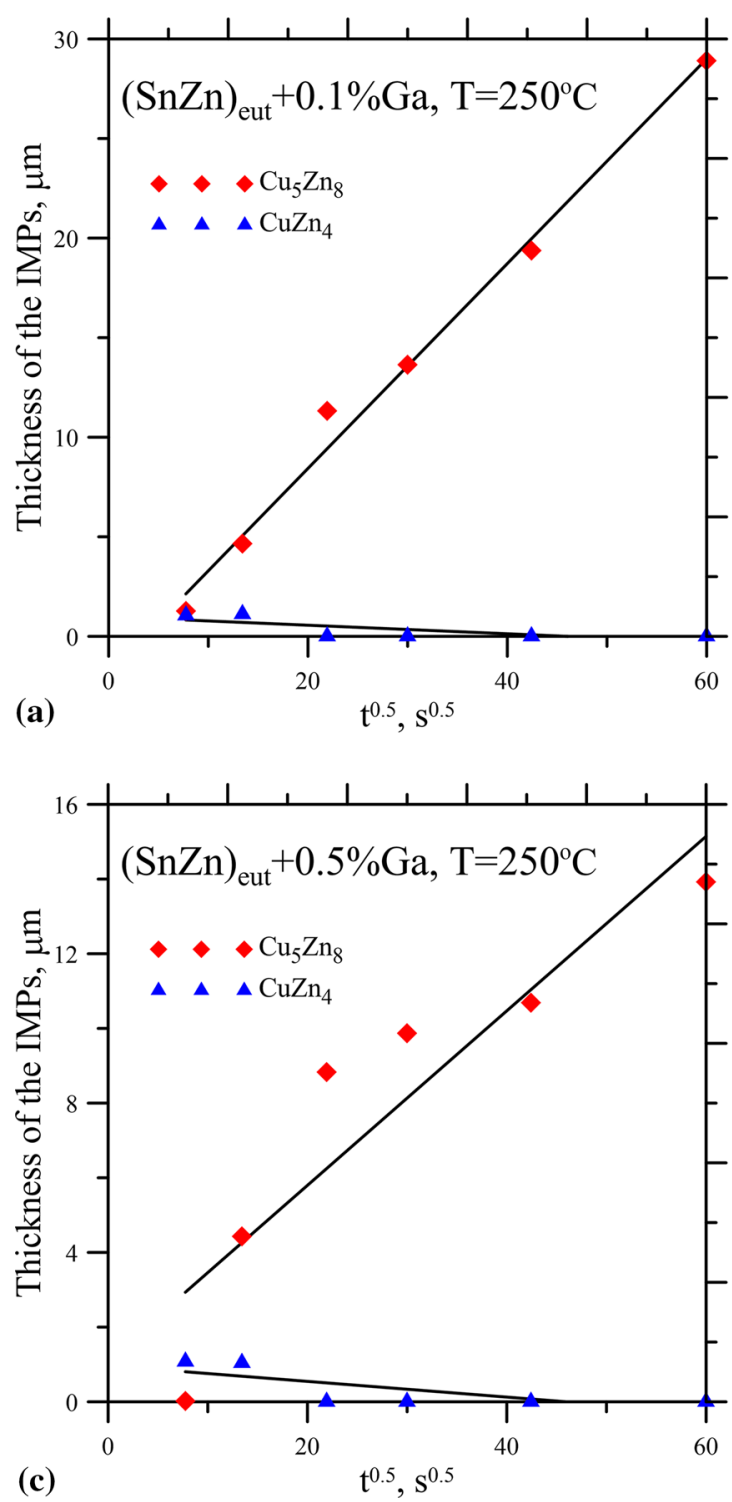


(d)

$$
\mathrm{t}^{0.5}, \mathrm{~s}^{0.5}
$$

Fig. 3 Thickness of IMC layer at $250{ }^{\circ} \mathrm{C}$ for $\mathrm{Sn}-8.9 \mathrm{Zn}-\mathrm{xGa} / \mathrm{Cu}$ couples, where x equals: (a) 0.1 , (b) 0.2 , (c) 0.5 , (d) 1.0 wt.\%

thickness of $\mathrm{Cu}_{5} \mathrm{Zn}_{8}$ increases in time, there is some disagreement regarding $\mathrm{CuZn}_{4}$. Lee and Shieu (Ref 15) reported for Sn$9 \mathrm{Zn} / \mathrm{Cu}$ couples that $\mathrm{CuZn}_{4}$ still exists after $480 \mathrm{~s}$ at 250 and $270{ }^{\circ} \mathrm{C}$, and its thickness is greater than after shorter wetting time. Mayappan (Ref 16), on the other hand, found both $\mathrm{CuZn} \mathrm{n}_{4}$ and $\mathrm{Cu} 5 \mathrm{Zn}_{8}$ after $60 \mathrm{~s}$ but only $\mathrm{Cu}_{5} \mathrm{Zn}_{8}$ layer after $180 \mathrm{~s}$ at $290{ }^{\circ} \mathrm{C}$. Gibbs free energy of $\varepsilon-\mathrm{CuZn}_{4}$ phase is less negative (higher) than that of $\beta-\mathrm{Cu}_{5} \mathrm{Zn}_{8}$ phase (Ref 17), meaning that the latter is thermodynamically more stable. This explains why $\mathrm{Cu}_{5} \mathrm{Zn}_{8}$ prevails over long time but does not explain why initially (at the beginning of wetting) there is also $\mathrm{CuZn}$ present. Using a kinetic model with thermodynamic data Terashima and Sasaki (Ref 18) predicted that for $\mathrm{Sn}-x \mathrm{Zn} / \mathrm{Cu}$ couples where $x<10 \mathrm{wt} . \%$, the $\mathrm{Cu}_{5} \mathrm{Zn}_{8}$ is the only phase that is formed, which contradicts earlier studies (Ref 15, 16). As we have recently shown for $\mathrm{Sn}-8.9 \mathrm{Zn}-x \mathrm{Cu} / \mathrm{Cu}$ couples (Ref 12 ), it seems that $\mathrm{CuZn}_{4}$ is formed first because initially the influx of $\mathrm{Zn}$ towards $\mathrm{Cu}$ surface is greater than dissolution of $\mathrm{Cu}$, so each $\mathrm{Cu}$ atom can bond with four $\mathrm{Zn}$ atoms. Once there is thin layer of $\mathrm{CuZn}_{4}$, the $\mathrm{Zn}$ diffuses through it and reacts with $\mathrm{Cu}$ to form
$\mathrm{Cu}_{5} \mathrm{Zn}_{8}$, which growths continuously. Further existence of $\mathrm{CuZn}_{4}$ depends on the influx of $\mathrm{Zn}$ from alloy to the interface.

The thickness of the IMC layer vs time is presented in Fig. 3, for different Ga content: (a) 0.1, (b) 0.2, (c) 0.5, and (d) 1.0 (wt.\%). As the thickness of the $\mathrm{Cu}_{5} \mathrm{Zn}_{8}$ layer increases, the thickness of the $\mathrm{CuZn}_{4}$ layer decreases. The thickness of $\mathrm{Cu}_{5} \mathrm{Zn}_{8}$ varies linearly with the square root of time, which is typical for diffusion-controlled growth (Ref 15). This can be expressed as $x=(k \times t)^{0.5}$, where: $\mathrm{x}$ is the thickness of the interlayer, $k$ is the growth constant, and $t$ is time. Growth and disappearing mechanism of $\mathrm{CuZn}_{4}$ is obviously different, nevertheless we show the data for $\mathrm{CuZn}_{4}$ in Fig. 3 for comparison purposes (the lines showing the decreasing tendency of $\mathrm{CuZn}_{4}$ serve as a guide for an eye only, as we did not determine the $k$ values for $\mathrm{CuZn}$ ). We found that, at $250{ }^{\circ} \mathrm{C}, k$ for $\mathrm{Cu}_{5} \mathrm{Zn}_{8}$ equals 0.51 for 0.1 wt. $\% \mathrm{Ga}, 0.52$ for 0.2 wt. $\% \mathrm{Ga}$, and 0.45 for 1.0 wt. $\%$ Ga. For 0.5 wt. $\% \mathrm{Ga}$ it is lower $(0.23)$. The growth constant $\mathrm{k}$ of $\mathrm{Cu}_{5} \mathrm{Zn}_{8}$ is lower for $\mathrm{Sn}-8.9 \mathrm{Zn}-0.5 \mathrm{Ga} /$ $\mathrm{Cu}$ because, for a long contact time (1800 and $3600 \mathrm{~s})$, the thickness of $\mathrm{Cu}_{5} \mathrm{Zn}_{8}$ is in this case lower than for the remaining 


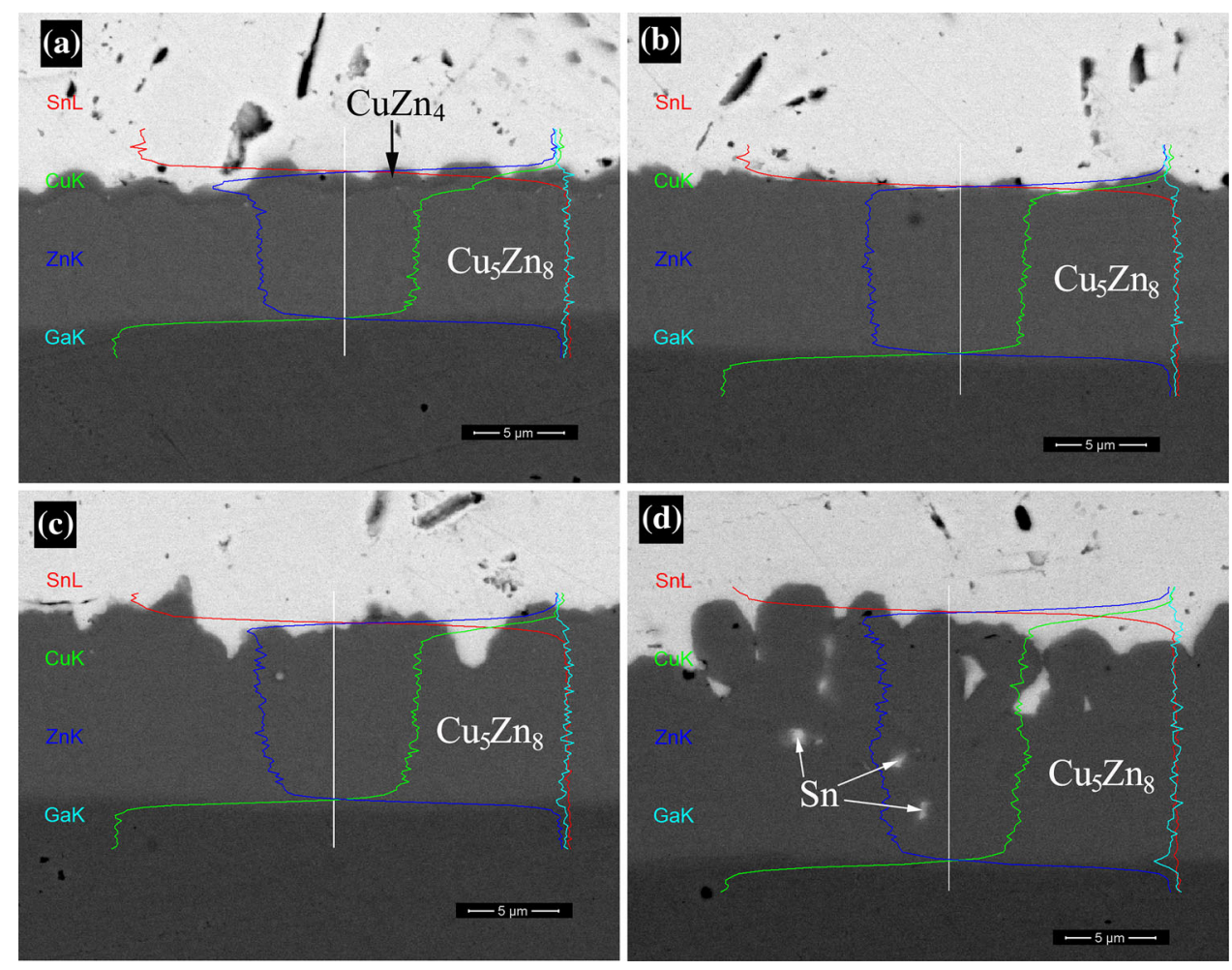

Fig. 4 Interfacial microstructure of Sn- $8.9 \mathrm{Zn}-1.0 \mathrm{Ga} / \mathrm{Cu}$ couples after $480 \mathrm{~s}$ at: (a) $230{ }^{\circ} \mathrm{C}$, (b) $250{ }^{\circ} \mathrm{C}$, (c) $280{ }^{\circ} \mathrm{C}$, (d) $320{ }^{\circ} \mathrm{C}$


Fig. 5 Zn-depleted zone in $\mathrm{Sn}-8.9 \mathrm{Zn}-0.5 \mathrm{Ga} / \mathrm{Cu}$ couples after spreading at $250{ }^{\circ} \mathrm{C}$ for $60 \mathrm{~s}$, and subsequent aging at $170{ }^{\circ} \mathrm{C}$ for: (a) $24 \mathrm{~h}$, (b) $240 \mathrm{~h}$, (c) $720 \mathrm{~h}$ 
interfaces. For short time of contact, the thickness of $\mathrm{Cu}_{5} \mathrm{Zn}_{8}$ is very similar for different $\mathrm{Ga}$ content and equals: $1.48 \pm 0.41 \mu \mathrm{m}$ at $60 \mathrm{~s}, 4.67 \pm 0.52 \mu \mathrm{m}$ at $180 \mathrm{~s}$, and $9.89 \pm 1.11 \mu \mathrm{m}$ at $480 \mathrm{~s}$. The fact that the thickness of the $\mathrm{Cu}_{5} \mathrm{Zn}_{8}$ IMC does not vary with different $\mathrm{Ga}$ concentrations for a short time of contact contradicts the earlier findings of Chen (Ref 10). According to Chen (Ref 10), the thickness of $\mathrm{Cu}_{5} \mathrm{Zn}_{8}$ increases with increased $\mathrm{Ga}$ content. Moreover, despite the lower temperature and short contact time $\left(235{ }^{\circ} \mathrm{C}\right.$ and $\left.30 \mathrm{~s}\right)$ (Ref 10) the thickness of $\mathrm{Cu}_{5} \mathrm{Zn}_{8}$ layer in the case of 0.5 wt.\% Ga alloy is 6 times greater than in present work. This difference, however, can be explained by different cooling regimes. In this study, the samples were transferred rapidly from the furnace to room temperature after the designated time. The samples of Chen et al. (Ref 10), however, were cooled slowly in the furnace, which kept the $\mathrm{Cu}_{5} \mathrm{Zn}_{8}$ growing. Slow cooling of samples might also explain why Chen et al. (Ref 10) did not observe the $\mathrm{CuZn}_{4}$ phase. A different character of IMC growth was observed for $\mathrm{Sn}-\mathrm{Zn}-\mathrm{In} / \mathrm{Cu}$ (Ref 13). In this case, despite dissolution of $\mathrm{In}$ in eutectic $\mathrm{Sn}-\mathrm{Zn}$, the $\mathrm{CuZn}_{4}$ layer continued to grow over time. For $\mathrm{Sn}-\mathrm{Zn}-\mathrm{Cu} / \mathrm{Cu}$ couples over a short time (60 s) (Ref 12), the IMC layer at the interface is twice as thick as the $\mathrm{Sn}-\mathrm{Zn}-\mathrm{Ga} / \mathrm{Cu}$ IMC layer, despite the formation of $\mathrm{Cu}-\mathrm{Zn}$ phases in $\mathrm{Sn}-\mathrm{Zn}-\mathrm{Cu}$ solder. This was different for $\mathrm{Cu} / \mathrm{Sn}-\mathrm{Zn}-\mathrm{Ag}-\mathrm{Cu} / \mathrm{Cu}$ (Ref 14) with a long contact time $(3600 \mathrm{~s})$. In this case, the $\mathrm{Cu}_{5} \mathrm{Zn}_{8}$ phase has a similar thickness to that of $\mathrm{Sn}-\mathrm{Zn}-0.5 \mathrm{Ga} / \mathrm{Cu}$, despite the addition of $\mathrm{Ag}$ and $\mathrm{Cu}$, which creates an IMC layer at the interface, all other phases disappear over time, and only the $\mathrm{Cu}_{5} \mathrm{Zn}_{8}$ layer remains.
The microstructures of Sn-8.9Zn alloys with $1.0 \mathrm{wt} . \% \mathrm{Ga}$ on $\mathrm{Cu}$ substrates after spreading test for $480 \mathrm{~s}$ at: $230,250,280$, and $320^{\circ} \mathrm{C}$, are presented in Fig. 4. The thickness of the $\mathrm{Cu}_{5} \mathrm{Zn}_{8}$ layer increases with temperature, and the $\mathrm{CuZn}$ layer is only observed at $230{ }^{\circ} \mathrm{C}$. At $320^{\circ} \mathrm{C}$, Sn inclusions start to appear in the $\mathrm{Cu}_{5} \mathrm{Zn}_{8}$ layer (Fig. 4d). As a result, the $\mathrm{Cu}_{5} \mathrm{Zn}_{8}$ layer looks scalloped from the solder side. The scalloped structure and $\mathrm{Sn}$ inclusion are caused by higher diffusion of $\mathrm{Cu}$ to the solder at $320{ }^{\circ} \mathrm{C}$. This results in the creation of a high $\mathrm{Cu}$ diffusion path in the $\mathrm{Cu}_{5} \mathrm{Zn}_{8}$ layer. A similar effect on the growth of the $\mathrm{Cu}_{5} \mathrm{Zn}_{8}$ layer was observed for $\mathrm{Sn}-\mathrm{Zn}-\mathrm{Ag}-\mathrm{Cu} / \mathrm{Cu}$ (Ref 14), where the addition of $\mathrm{Ag}$ and $\mathrm{Cu}$ formed $\mathrm{AgZn}_{3}$ and $\mathrm{CuZn}_{4}$ layers. However, with increasing time, these layers are dissolved.

\subsection{Aging of Joints}

After wetting for $60 \mathrm{~s}$ at $250{ }^{\circ} \mathrm{C}$, cross-sectioned samples were subjected to aging treatment. The $\mathrm{Sn}-8.9 \mathrm{Zn}-0.5 \mathrm{Ga} / \mathrm{Cu}$ couples, after aging at $170{ }^{\circ} \mathrm{C}$ for 24,240 , and $720 \mathrm{~h}$, are presented in Fig. 5. With increasing aging time the intermetallic layer at the $\mathrm{Sn}-8.9 \mathrm{Zn}-0.5 \mathrm{Ga} / \mathrm{Cu}$ interface gets thicker, but after 10 days the IMC layer becomes discontinuous. Zinc precipitates start to disappear in the solder close to the interface, and the size of zinc-depleted zone grows over time, as shown in Fig. 5. Large, irregular precipitates of $\mathrm{Cu}_{5} \mathrm{Zn}_{8}$ are formed in the solder close to the interface, because diffusion of $\mathrm{Cu}$ is much higher than that of $\mathrm{Zn}$ (Ref 19). The thickness of the IMC layer increases from the solder side due to the $\mathrm{Cu}$ subsequently
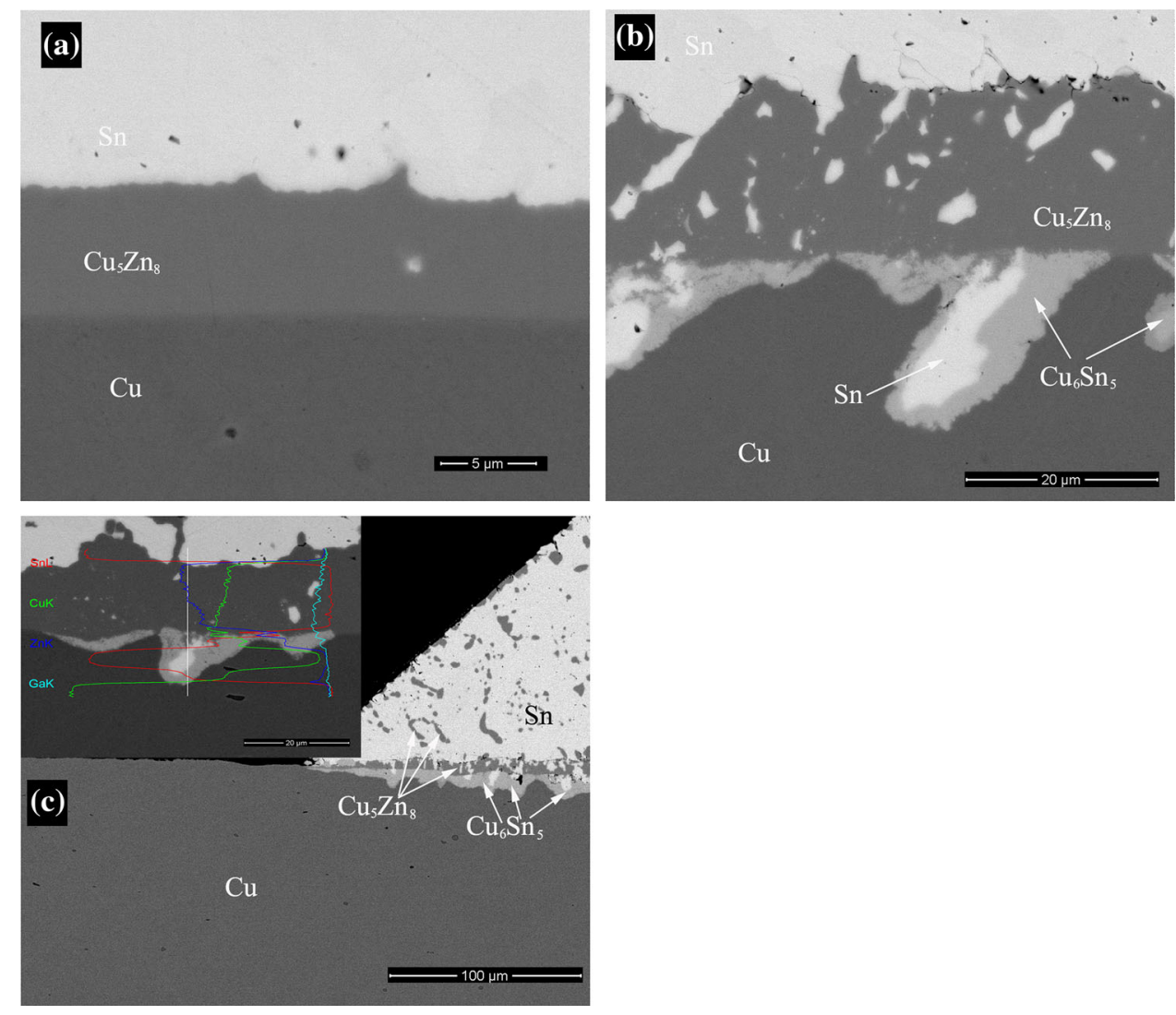

Fig. 6 Interfacial microstructure of Sn-8.9Zn- $0.5 \mathrm{Ga} / \mathrm{Cu}$ after spreading at $250{ }^{\circ} \mathrm{C}$ for $60 \mathrm{~s}$, and subsequent aging at $170{ }^{\circ} \mathrm{C}$ for: (a) $24 \mathrm{~h}$, (b) $240 \mathrm{~h}$, (c) $720 \mathrm{~h}$ 


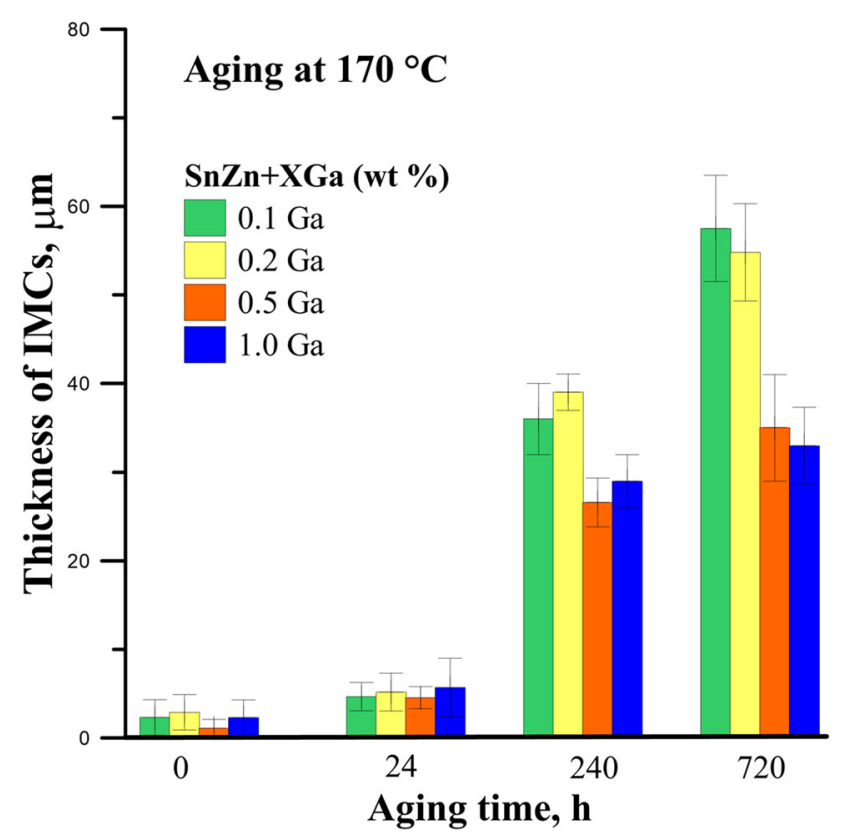

Fig. 7 Thickness of IMC layer after aging process at $170{ }^{\circ} \mathrm{C}$ for $\mathrm{Sn}-\mathrm{Zn}-x \mathrm{Ga}$ alloys for different time

reacting with the $\mathrm{Zn}$ in the solder. Also, after 10 days of aging, the surface of the substrate in contact with the $\mathrm{Cu}_{5} \mathrm{Zn}_{8}$ layer is no longer smooth. The same character of growth of the $\mathrm{Cu}_{5} \mathrm{Zn}_{8}$ layer at the interface after the aging process was earlier observed for Sn-Zn-Bi/Cu (Ref 20) and Sn-Zn-Ag-Cu/Cu (Ref 14). A similar Zn-depleted zone was earlier observed by Ref 20 and 19. Wang et al. (Ref 19) studied aging of $\mathrm{Sn}-\mathrm{Zn}_{\text {eut }} / \mathrm{Cu}$ joints, which were prepared with short contact time and either very slow or rapid cooling. They explained that the initial thin intermetallic layer, when subjected to aging after rapid cooling, is not a good barrier for diffusion of $\mathrm{Cu}$. But, after very slow cooling, a $\mathrm{Cu}_{5} \mathrm{Zn}_{8}$ layer formed due to slow growth achieves equilibrium, and becomes an effective barrier for the fast diffusion of $\mathrm{Cu}$ to the solder (Ref 19).

Figure 6, shows higher magnification micrographs of the $\mathrm{Sn}-8.9 \mathrm{Zn}-0.5 \mathrm{Ga} / \mathrm{Cu}$ interface after aging treatment. The inclusions of $\mathrm{Sn}$ and another phase are observed from the $\mathrm{Cu}$ substrate side after $240 \mathrm{~h}$. Based on EDS analysis results, this phase is identified as $\mathrm{Cu}_{6} \mathrm{Sn}_{5}$. It is a product of the reaction of $\mathrm{Cu}$ with $\mathrm{Sn}$, which diffused through the $\mathrm{Cu}_{5} \mathrm{Zn}_{8}$ layer from the $\mathrm{Zn}$-depleted zone. Though the $\mathrm{Cu}_{5} \mathrm{Zn}_{8}$ phase has the lowest Gibbs free energy during aging process, growth of $\mathrm{Cu}_{6} \mathrm{Sn}_{5}$ is possible because there is no "free" $\mathrm{Zn}$ left in the $\mathrm{Zn}$-depleted zone. Therefore it is not possible for phases from the $\mathrm{Cu}-\mathrm{Zn}$ system to form. With increasing aging time, bigger inclusions of $\mathrm{Sn}$ and greater growth of the $\mathrm{Cu}_{5} \mathrm{Zn}_{8}$ IMC layer were observed.

The thickness of the IMC layer at the $\mathrm{Sn}-8.9 \mathrm{Zn}-x \mathrm{Ga} / \mathrm{Cu}$ interface, after aging at $170{ }^{\circ} \mathrm{C}$ for different times is presented in Fig. 7. After aging for $24 \mathrm{~h}$, the IMC layer shows similar thickness for all alloys regardless of Ga content. When aging time is increased to 240 and $720 \mathrm{~h}$, the IMC layer grows more for 0.1 and $0.2 \mathrm{wt} . \% \mathrm{Ga}$ than for 0.5 and $1.0 \mathrm{wt} . \% \mathrm{Ga}$. The effect of aging time on the interfacial microstructure evolution of $\mathrm{Sn}-9 \mathrm{Zn}-0.5 \mathrm{Ga} / \mathrm{Cu}$ couples was studied by Ye et al. (Ref 11). They subjected the interfaces obtained in the wetting balance test to aging at $100{ }^{\circ} \mathrm{C}$ for 100 and $1000 \mathrm{~h}$. Despite the lower temperature, their findings agree with our results, in that the thickness of the $\mathrm{Cu}_{5} \mathrm{Zn}_{8}$ layer increases and $\mathrm{Zn}$ in the solder is consumed by $\mathrm{Cu}$ diffusing from the substrate. $\mathrm{Sn}$ also starts to diffuse in the opposite direction, through the $\mathrm{Cu}_{5} \mathrm{Zn}_{8}$ layer, and $\mathrm{Cu}_{6} \mathrm{Sn}_{5}$ is formed on the side of the substrate. Mayappan (Ref 20) shows that the addition of $\mathrm{Bi}$ to $\mathrm{Sn}-\mathrm{Zn}$ caused the thickness of the IMC layers to reduce after aging at $150{ }^{\circ} \mathrm{C}$, compared to eutectic Sn-Zn. In our case, the obtained thicknesses of 35 and $33 \mu \mathrm{m}$ for 0.5 and 1.0 (wt.\%) Ga additions to $\mathrm{Sn}-\mathrm{Zn}$ are similar to eutectic $\mathrm{Sn}-\mathrm{Zn}(33 \mu \mathrm{m})$ (Ref 20). However, the aging treatment temperature for $\mathrm{Sn}-\mathrm{Zn}$ was $20{ }^{\circ} \mathrm{C}$ lower compared to that for $\mathrm{Sn}-\mathrm{Zn}-\mathrm{Ga}$ alloys.

\section{Conclusion}

The addition of Ga to Sn-Zn alloys does not have a strong effect on spreadability as a function of time and temperature. The obtained results of spreading area for $\mathrm{Sn}-\mathrm{Zn}-\mathrm{Ga}$ alloys are close to the literature data (Ref 10). In the soldering process, the thickness of the $\mathrm{Cu}_{5} \mathrm{Zn}_{8}$ IMC layer increases with time and temperature. For the $\mathrm{Sn}-\mathrm{Zn}-0.5 \mathrm{Ga}$ alloy, growth of $\mathrm{Cu}_{5} \mathrm{Zn}_{8}$ IMC layer is the slowest. During aging, a $\mathrm{Zn}$-depleted zone is observed on the side of the solder and $\mathrm{Cu}_{6} \mathrm{Sn}_{5}$ is found on the side of the substrate after 10 days. The initial thin $\mathrm{Cu}_{5} \mathrm{Zn}_{8}$ layer is no barrier for $\mathrm{Sn}$ and $\mathrm{Cu}$ diffusion during aging.

\section{Acknowledgement}

This work was financed by the National Science Centre Poland grant 2013/09/D/ST8/03991, in the years 2014-2017. The authors are grateful to Dr P. Bobrowski for SEM-EDS analysis, performed in Accredited Testing Laboratories at the Institute of Metallurgy and Materials Science, Polish Academy of Sciences.

\section{Open Access}

This article is distributed under the terms of the Creative Commons Attribution 4.0 International License (http://creativecommons. org/licenses/by/4.0/), which permits unrestricted use, distribution, and reproduction in any medium, provided you give appropriate credit to the original author(s) and the source, provide a link to the Creative Commons license, and indicate if changes were made.

\section{References}

1. L. Zhang, S. Xue, L. Gao, Z. Sheng, H. Ye, Z. Xiao, G. Zeng, Y. Chen, and S. Yu, Development of Sn-Zn Lead-Free Solders Bearing Alloying Elements, J. Mater. Sci., 2010, 21, p 1-15

2. S. Liu, S. Xue, P. Xue, and D. Luo, Present Status of Sn-Zn Lead-Free Solders Bearing Alloying Elements, J. Mater. Sci., 2015, 26, p 4389-4411

3. T.J. Anderson and I. Ansara, The Ga-Sn (Gallium-Tin) System, J. Phase Equilib., 1992, 13, p 181-189

4. J. Dutkiewicz, Z. Moser, L. Zabdyr, D.D. Gohil, T.G. Chart, I. Ansara, and C. Girard, The Ga-Zn (Gallium-Zinc) System, Bull. Alloy Phase Diag., 1990, 11, p 77-82

5. J.-M. Song, N.-S. Liu, and K.-L. Lin, Microstructures, Thermal and Tensile Properties of Sn-Zn-Ga Alloys, Mater. Trans., 2004, 45, p 776782

6. F.-Y. Hung, T.-S. Lui, L.-H. Chen, and P.-H. Chen, Influence of Ga addition on Microstructure, Tensile Properties and Surface Oxide Film 
Characteristics of Microelectronic Sn-9Zn-xGa Solders, Mater. Trans. 2008, 49, p 1496-1502

7. T. Gancarz, Physical, Thermal, Mechanical Properties and Microstructural Characterization of Sn-9Zn-XGa Alloys, Metall. Mater. Trans. A, 2016, 47A, p 326-333

8. Y. Zhang, T. Liang, and M.A. Jusheng, Phase Diagram Calculation on Sn-Zn-Ga Solders, J. Non-Cryst. Solids, 2004, 336, p 153-156

9. D. Zivkovic, L. Balanovic, D. Manasijevic, T. Holjevac Grguric, D. Cubela, and A. Mitovski, Comparative Thermodynamic Analysis and Phase Diagram Prediction of the Ga-Sn-Zn System, Int. J. Mater. Res., 2013, 104, p 26-34

10. W.X. Chen, S.B. Xue, and H. Wang, Wetting Properties and Interfacial Microstructures of $\mathrm{Sn}-\mathrm{Zn}-\mathrm{xGa}$ Solders on $\mathrm{Cu}$ Substrate, Mater. Design, 2010, 31, p 2196-2200

11. H. Ye, S. Xue, J. Luo, and Y. Li, Properties and Interfacial Microstructure of Sn-Zn-Ga Solder Joint with Rare Earth Pr Addition, Mater. Design, 2013, 46, p 816-823

12. P. Fima, J. Pstrus, and T. Gancarz, Wetting and Interfacial Chemistry of $\mathrm{SnZnCu}$ Alloys with $\mathrm{Cu}$ and $\mathrm{Al}$ Substrates, J. Mater. Eng. Perform., 2014, 23, p 1530-1535

13. T. Gancarz, P. Fima, and J. Pstruś, Thermal Expansion, Electrical Resistivity, and Spreading Area of Sn-Zn-In Alloys, J. Mater. Eng. Perform., 2014, 23, p 1524-1529
14. T. Gancarz and J. Pstrus, Formation and Growth of Intermetallic Phases at the Interface in the $\mathrm{Cu} / \mathrm{Sn}-\mathrm{Zn}-\mathrm{Ag}-\mathrm{Cu} / \mathrm{Cu}$ Joints, J. Alloy. Compd., 2015, 647, p 844-856

15. C. Lee and F. Shieu, Growth of Intermetallic Compounds in the Sn9Zn/Cu Joint, J. Electron. Mater, 2006, 35, p 1660-1664

16. R. Mayappan, R.A. Zaman, Z.Z. Abidin et al., Growth of CuZn5 and $\mathrm{Cu} 5 \mathrm{Zn} 8$ Intermetallic Compounds in the $\mathrm{Sn}-9 \mathrm{Zn} / \mathrm{Cu}$ Joint During Liquid State Aging, Adv. Mater. Res., 2011, 173, p 90-95

17. Y. Huang, S. Chen, C. Chou, and W. Gierlotka, Liquidus Projection and Thermodynamic Modeling of Sn-Zn-Cu Ternary System, J. Alloy. Compd., 2009, 477, p 283-290

18. S. Terashima and T. Sasaki, Prediction of Intermetallic Compound Formation Sequences in Pseudo Binary Diffusion Couples: Experimental Examinations for $(\mathrm{Sn}-\mathrm{xZn}) / \mathrm{Cu}(x=2,5,10,15,20$ and 25 mass\%) by Kinetic Model with Thermodynamic Data Using MDR Diagram, Mater. Trans., 2014, 55, p 1750-1754

19. J.-Y. Wang, C.-F. Lin, and C.-M. Chen, Retarding the Cu5Zn8 Phase Fracture at the Sn-9 wt.\% Zn/Cu Interface, Scripta Mater, 2011, 64, p 633-636

20. R. Mayappan and Z. Ahmad, Effect of Bi Addition on the Activation Energy for the Growth of Cu5Zn8 Intermetallic in the Sn-Zn Lead-Free Solder, Intermetallics, 2010, 18, p 730-735 